\title{
Analisa Dan Implementasi Metode Knowledge Base Recomendation Dalam Penerimaan Karyawan
}

\author{
Agustina Simangunsong \\ Manajemen Informatika, STMIK Pelita Nusantara Medan, Jl. Iskandar Muda No.1 Medan \\ Email : agustinasimangunsong93@gmail.com
}

\begin{abstract}
Rekomendasi usaha pertama yang dilakukan perusahaan untuk memperoleh karyawan yang qualified dankempeten yang akan ikut sarta mengerjakan semua pekerjaaan pada perusahaan. Untuk mempermudah perusahaan maka perusahaan membuat berbasis web (website) untuk menyeleksi karyawan dimana perusahaan akan mengambil data para pelamar sebagai bahan pertimbangan. Metode Knowledge Based Recommendation sering juga di kenal istilah metode penilaian. konsep dasar metode Knowledge based recommendation adalah mencari penilaian, ketanggapan dan prestasi. Metode ini membutuhkan proses normalisasi keputusan kesuatu skala yang dapat di perbandingkan dengan semua alternative yang ada. sistem rekomendasi ini dirancang untuk memberikan kemudahan pada pelamar dan perusahaan yang akan menggunakan sistem rekomendasi karyawan.
\end{abstract}

Kata kunci : Sistem Recomendasi, Knowledge based recomendation

\section{Pendahuluan}

Sistem rekomendasi di defenisikan sebagai aplikasi pada website e-commerce untuk mengusulkan informasi dan menyediakan fasilitas yang di inginkan pengguna dalam membuat suatu keputusan. Tidak hanya pada teknologi perangkat keras atau perangkat lunak saja. Salah satu metode komputasi yang cukup berkembang saat ini adalah sistem rekomendasi. Kunci keberhasilan di era global di antaranya adalah kemampuan di dalam proses pengambilan keputusan secara cepat, tepat sasaran dan dapat dipertanggungjawabkan. Mempunyai banyak data dan informasi sering kali menjadi hal yang membuat bingung jika tidak mampu mengolahnya dengan cepat menjadi pilihan-pilihan terbaik. Namun, sebelum itu dilakukan dibutuhkan adanya suatu standart atau kriteria yang mampu menjawab satu pertanyaan penting mengenai seberapa baik pilihan dapat memecahkan suatu masalah yang dihadapi.

Survei yang dilakukan oleh Stanford Research Institute, Harvard University dan Carnegie foundation menyimpulkan: bahwa lima belas persen $(15 \%)$ dari alasan mengapa seseorang berhasil meraih keberhasilan dalam pekerjaan banyak ditentukan oleh penguasaan pengetahuan dan keterampilan mengenai manusia. Survei yang lain pada 16 (enam belas) jenis industri di Amerika menunjukan bahwa ternyata persentasi seseorang tidak ditentukan oleh faktor pendidikan formal apakah seseorang tersebut sarjana atau bukan sarjana, bukan oleh faktor jenis kelamin apakah seseorang itu laki-laki atau perempuan, bukan oleh ras apakah mereka itu kulit putih atau kulit hitam, dan juga bukan oleh umur apakah diatas 40 tahun atau di bawah 40 tahun.

\section{Landasan Teori}

\subsection{Knowledge-based recommendation}

Knowledge-based recommendation merupakan metode yang memanfaatkan perzonalization rule pada knowledge-based (basis pengetahuan). Perzonalization rule merupakan aturan-aturan yang dirancang pada basis pengetahuan dengan skala prioritas tertentu. Skala prioritas diatur tingkatannya berdasarkan prediksi prioritas kebutuhan pelanggan terhadap suatu produk (item). Produk yang memenuhi prioritas terbanyak akan dijadikan rekomendasi bagi pelanggan.

\subsection{Pengertian Utility -based recommendation}

Utility based recommendation merupakan metode yang memanfaatkan score (nilai kegunaan ) suatu item sebagai acuannya. Suatu item dinilai pada tiap domain penilaian, setelah itu score item pada tiap domain dihitung secara total. item yang memiliki total score terbesarlah yang akan dijadikan rekomendasi bagi perusahaan. Prioritas domain penilaian diatur oleh perusahaan, dengan kata lain domain penilaian dengan tingkat prioritas lebih tinggi akan memiliki score lebih tinggi pula. Metode ini hampir sama dengan Metode Bayasian Network.

\subsection{Pengertian User-based collaborative filtering}

User-based collaborative filtering merupakan metode rekomendasi yang didasari atas adanya kesamaan kebutuhan perusahaan dan pelamar. Kesamaan kebutuhan pelanggan dalam suatu komunitas dideteksi, setelah 
itu dilakukan pemilihan berdasarkan tingkat kesamaan tertinggi. Kegiatan pelanggan lain (dalam komunitas yang sama) dengan tingkat kesamaan kebutuhan yang tinggi akan dijadikan acuan rekomendasi bagi pelamar yang membutuhkan rekomendasi

\subsection{Pengertian Item-based collaborative filtering}

Aplikasi berbasis web dapat digunakan untuk berbagai macam tujuan yang berbeda. Sebagai contoh palikasi berbasis web dapat digunakan untuk membuat invoice dan dan memberikan caya yang mudah dalam penyimpanan data di database. Aplikasi ini juga dapat dipergunakan untuk mengatur persediaan karena fitur tersebut sangat berguna khususnya bagi mereka yang berbisnis ritel. Bukan hanya itu, aplikasi berbasis web juga dapat bekerja memonitoring sistem dalam hal tampilan. Bahkan jumlah dari aplikasi berbasis web sudah tidak terhitung lagi, yakni dapat di desain dan di sesuaikan untuk berbagai jenis industri.

Selain fungsi-fungsi tersebut, salah satu ke unggulan kompetitif dari aplikasi berbasis web adlah bahwa aplikasi tersebut ringan dan dapat di akses dengan cepat melalui browser dan koneksi internet atau intranet ke server. Ini berarti bahwa pengguna dapat mengakses data atau bahkan komputer PC di rumah mereka dengan mudah, tidak seperti aplikasi-aplikasi dekstop dimana pengguna harus menginstal perangkat lunak atau aplikasi yang diperlukan hanya untuk mengakses data informasi.

\section{Implementasi}

\subsection{Halaman Registrasi}

Halaman ini digunakan untuk menampilkan user registrasi untuk pendaftaran berupa biodata dan untuk mendapatkan ID member dan kata sandi.

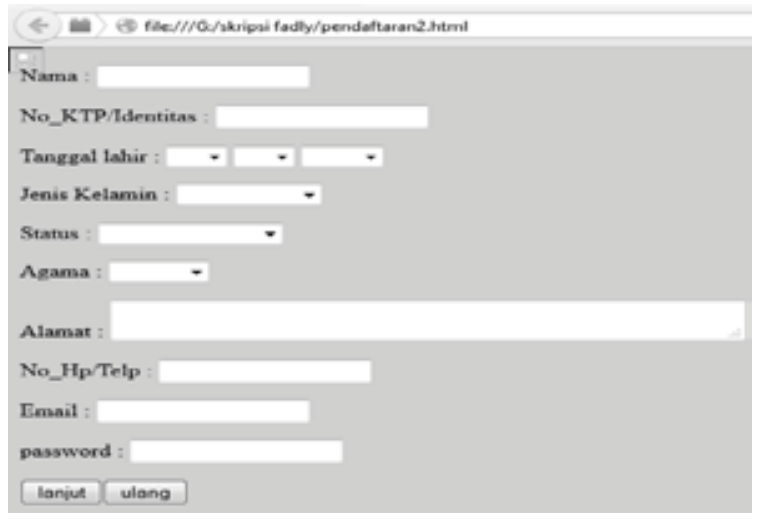

Algoritma :

Gambar 1. Menu registrasi

1. Buka web browser

2. Ketik pada URL file://G:/skripsi\%20fadly/pendaftaran2.html

3. Maka akan muncul gambar diatas

4. Maka isi semua kolom untuk melengkapi data

5. Lalu klik tombol lanjut

\subsection{Data Setelah Registrasi}

Halaman ini digunakan untuk menampilkan menu setelah kita berhasil mendaftar dan mendapat ID dan password

$$
\begin{aligned}
& \text { Lingt Dale }
\end{aligned}
$$

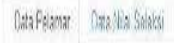

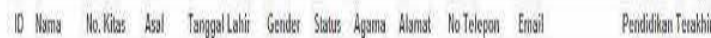

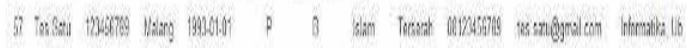


Gambar 2. Data Pelamar

Algoritma :

1. Setelah melakukan pendaftaran

2. Maka muncul lihat data

3. Berfungsi untuk melihat data yang sudah di input

\subsection{Data Range}

Halaman ini digunakan untuk penilaian yang telah dilakukan dengan 4 cara penilaian yaitu, pendidikan, prestasi, kemampuan, kecerdasan.

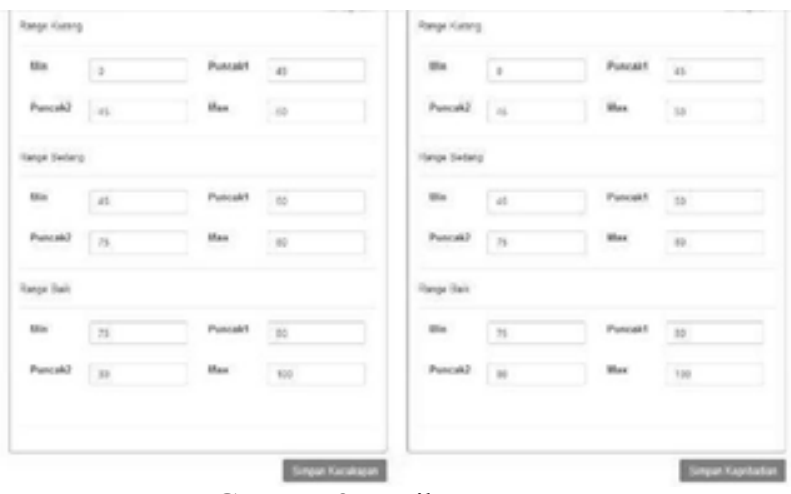

Algoritma :

Gambar 3. Hasil Data Range

1. Hasil dari test rekomendasi

2. Maka setelah selesai data di simpan

3. Data dapat di ubah oleh admin

\section{Kesimpulan}

Berdasarkan pembahasan yang dilakukan mengenai sistem rekomendasi penerimaan karyawan ini, maka penulias mengambil beberapa kesimpulan sebagai berikut :

1. Menerapkan metode Knowledge Based recommendation dalam seleksi rekomendasi karyawan dengan cara menganalisa yang menjadi kriteria penilaian, sehingga analisa tersebut sebuah keputusan dapat menjadi lebih daik dan terukur.

2. Aplikasi berbasis web ini menggunakan metode Knowledge based recommendation dengan menggunakan PHP, MySQL dan Notepad++ dapat digunakan untuk membuat program penyeleksian dengan akurasi yang tepat.

\section{Referensi}

[1]. Al-Bahra bin Ladjamudin. 2005. Analisis dan Desain Sistem Informasi. Yogyakarta: Graha Ilmu.

[2]. Andi.2008. Web dengan PHP dan MySQL. Madiun

[3]. http://definisipengertian.com/2012/pengertian-definisi-karyawan- menurut-para-ahli/

[4]. https://inisantoso.wordpress.com/2012/09/25/definisi-pekerjaan/

[5]. http://thelittlebomb.blogspot.com/2013/01/pengertian-kepribadian-secara-umum.html

[6]. id.wikipedia.org/wiki/Sistem

[7]. Kadir, Abdul. 2002. Dasar Pemograman Web. Yogyakarta: Andi

[8]. My Earth Makasar 2008 [http://meylonesome.blogspot.com/2008/12/perancangan-sistem-dan-analisis.html]

[9]. Ricci, f. "Pengenalan Sistem Rekomendasi “ , 2002.yogyakarta 